\title{
Pendidikan Formal dan Pendidikan Kebudayaan : Dinamika Buruh Tenun Pandai Sikek
}

\author{
Oleh: Jonson Handrian Ginting
}

\section{A. Pendahuluan}

Apabila anda sedang membaca artikel ini, silahkan rogoh saku dan temukan pecahan uang Rp5.000, lihat dengan baik gambar apa yang ditetapkan pemerintah Indonesia pada kedua belah sisi pecahan uang tersebut. Kita akan mendapati bahwa di kedua belah sisi pecahan uang tersebut adalah gambar tuangku Imam Bonjol dan gambar aktivitas bertenun ${ }^{1}$ Pandai Sikek. Menurut saya, bahwa salah satu alasan pemerintah meletakkan gambar tersebut di pecahan uang tersebut adalah bentuk dari pengakuan, eksistensi dan apresiasi pemerintah kepada tuanku Imam Bonjol dan tenun Pandai Sikek. Mungkin bayak yang mengetahui tuanku imam Bonjol karena beliau adalah salah satu pahlawan nasional serta menjadi bahan ajar di sekolah, tapi dari beberapa perbicagan saya dengan teman-teman sejawat, tidak banyak yang tau dan mengeri tentang tenun Pandai Sikek, bahkan mereka tidak menyadari bahwa gambar dibalik Tuanku Imam Bonjol Pada pecahan uang Rp5.000 adalah aktivitas bertenun di Pandai Sikek.

Pandai Sikek adalah salah satu Nagari yang berada di kabupaten Tanah Datar, Sumatera Barat. Di alam Minangkabau² sendiri, komoditas berupa kain tenun merupakan barang yang memiliki nilai tinggi karena memiliki fungsi-fungsi di berbagai upacara. Dengan demikian, semestinya masyarakat harus memiliki kain tenun terutama perempuan. leluhur dan tetua masyarakat Pandai Sikek dahulu mengikrarkan kemahiran bertenun sebagai "pusako" yang harus dijaga dan dilestarikan serta tidak boleh diajarkan kepada orang lain bahkan ke kampung atau desa sebelah. Sebagai instrumen kontrol sosial, muncul buah bibir yang berkembang bahwa "malu rasanya apabila perempuan Pandai Sikek tidak bisa bertenun". Dengan mengusung sistem kekerabatan Matrilineal, regenerasi kemahiran bertenun juga mengikuti garis keturunan Ibu. Artinya, laki-laki yang menikahi wanita Pandai Sikekpun tidak diperbolehkan belajar bertenun, pengetahuan-pengetahuan tentang bertenun nantinya akan diregenerasikan ke anak dan keturunannya.

Aktivitas bertenun di Pandai Sikek masih bisa ditemui sampai sekarang. Namun permasalahannya adalah proses regenerasi pengetahuan bertenun tidak seideal yang diharapkan segenap masyarakat karena jumlah penenun di Pandai Sikek didominasi oleh orang tua, anak-anak mereka bahkan ada yang tidak bisa sama sekali. Hal ini bukan disengaja, banyak faktor yang mempengaruhi dan menghambat keberlangsungan proses transfer pengetahuan tersebut, salah satu faktor penting adalah pendidikan formal dan sistem kapitalisme yang dibangun. Pada titik ini, pendidikan formal sebagai media belajar yang diyakini masyarakat berubah menjadi faktor penghambat eksistensi kebudayaan.

Tulisan ini bertujuan untuk memaknai bagaimana institusi pendidikan formal berubah menjadi instrumen simbolik dan merupakan bahasa perlawanan masyarakat terhadap kebudayaannya sendiri dengan alasan-alasan tertentu yang kemudian secara tidak langsung

\footnotetext{
${ }^{1}$ Istilah "bertenun" digunakan sesuai transformasi bahasa Minang ke bahasa Indonesia dengan kata dasar "batanun"

2 Penggunaan "alam Minangkabau" merujuk pada nilai dan Norma lahir batin aktivitas masyarakat Minangkabau, konsep ini tidak terbatas pada batas-batas administratif wilayah Sumatera Barat saja karena dengan konsep merantaunya, masyarakat Minangkabau sudah bermigrasi sejak beberapa abad sebelumnya.
} 
akan mempengaruhi proses regenerasi pengetahuan-pengetahuan bertenun di Pandai Sikek itu sendiri. Masalah ini kemudian dianggap serius karena menjadi faktor penghambat keberlangsungan serta eksistensi dari kebudayaan lokal tersebut, dan kemudian sangat disayangkan ketika pengetahuan tersebut dipelajari dan dilestarikan oleh "orang" dari desa bahkan suku bangsa lain. Pergolakan masalah ini tidak hanya terkait dengan proses sosialisasi dari satu generasi ke generasi lain, tapi juga sangat erat kaintannta dengan eksistensi budayabudaya lokal yang diakui, lebih jauh lagi, permasalahan ini terkait dengan identitas sebuah komunitas dan masyarakat.

\section{B. Mata Pencaharian dan Kain Tenun.}

Nagari ${ }^{3}$ Pandai Sikek berada di dataran tinggi, lokasinya tepat dibawah kaki gunung Singgalang, dengan demikian hawa dan udara terasa sangat sejuk dan dingin. Tidak jarang Nagari ini menjadi salah satu lokasi wisata berbagai wisatawan asing bahkan wisatawan lokal, baik untuk menikmati alam atau belanja berbagai hasil kerajinan tangan masyakarat Pandai Sikek. Di jalan utama, pengunjung akan melihat ruko-ruko berjejer di sebelah kanan dan kiri jalan. Apabila pengunjung berjalan ke berbagai sudut desa, seringkali terdengar depakan "panta" di tiap rumah, tanda mereka sedang mengerjakan kain tenun. Pandai Sikek sebenarnya bagian dari sejarah panjang pembaharuan islam di Minangkabau, di Nagari ini dimakamkan salah seorang tokoh penting pembaharuan islam selain Tuanku Imam Bonjol, yaitu Haji Miskin ${ }^{5}$. Oleh karena itu Nagari Pandai Sikek tidak hanya kaya secara pengetahuan lokal, namun juga kaya dengan nilai historis. Mata pencaharian masyarakat pada umumnya adalah sektor pertanian. Pemilihan mata pencaharian sebagai petani dilatarbelakangi oleh aspek historis, lingkungan alam dan bahan makanan yang dikonsumsi oleh masyarakat itu sendiri. Lingkungan alam yang cocok untuk pertanian merupakan faktor utama yang sangat berpengaruh, rata-rata semua lahan pertanian yang dimanfaatkan adalah lahan tanah yang subur, alasan lain juga bahwa Nagari Pandai Sikek adalah salah satu Nagari yang diapit oleh Gungung Singgalang dan Gunung Merapi Sumatera Barat. Tersedianya lahan pertanian yang memadai untuk masing masing masyarakat memberikan pengaruh yang cukup besar terhadap bentuk mata pencaharian sebagai petani mengingat makanan pokok masyarakat adalah beras (nasi).

Sejalan dengan pernyataan di atas, sistem masyarakat masyarakat pedesaan dalam pemilihan usaha mata pencaharian mengarah kepada usaha pemenuhan kebutuhan utama sehari-hari, untuk itu sektor pertanian menjamin bahwa sebagian besar kebutuhan sehari-hari dapat dipenuhi dengan baik. Namun, pernyataan ini biasanya hanya berlaku untuk laki-laki saja. Perempuan yang dirumah juga mengerjakan hal-hal yang produktif salah satunya bertenun. Bertenun di Nagari Pandai Sikek sudah dilakukan sejak ratusan tahun lalu. Perempuan-perempuan yang tidak bertani menghabiskan waktu untuk bertenun di rumah walaupun memang tidak semua dari wanita atau perempuan Pandai Sikek bertenun.

Kalau diteliti lebih lanjut, industri tenun Pandai Sikek merupakan industri kecil (home industry) yang dilakukan rakyat dalam lingkungan rumah tangga pemilik perusahaan. Berkembangnya industri kecil biasanya berawal dari industri tradisional dan merupakan gabungan dari beberapa kelompok yang menggunakan sumber kerja dan materi dasar lokal

\footnotetext{
${ }^{3}$ Nagari adalah pembagian wilayah administratif sesudah kecamatan di provinsi Sumatera Barat, Indonesia. Sesuai dengan Undang undang Nomor 32 Tahun 2004 tentang Pemerintahan Daerah, Istilah Nagari menggantikan istilah desa, yang digunakan di provinsi lain di Indonesia. Lebih lanjut lihat di https://id.wikipedia.org/wiki/Nagari

${ }^{4}$ Panta adalah Alat utama pembuat kain tenun

${ }^{5}$ Walaupun ada claim dari pihak lain bahwa makam Haji Miskin yang sebenarnya adalah di desa....
} 
yang belum terkenal. Industri kecil pada saat itu dijalankan oleh perusahaan keluarga dalam skala kecil. Lambat laun industri kecil itu mengalami perkembangan sehingga hasilnya dapat mencapai pasar lokal, wilayah regional, bahkan internasional (Mizuno, 1996: 24).

Di Pandai Sikek, hampir setiap rumah memiliki panta. Apabila pada sektor industri lain lakilaki lebih diutamakan dan diharapkan dalam perekrutan buruh $^{6}$, pada sektor industri tenun (khususnya di Pandai Sikek) biasanya didominasi oleh perempuan karena pekerjaan ini harus dikerjakan dengan telaten dan sabar. Gagasan bahwa kaum wanita merupakan pekerja inferior secara alamiah susah untuk dibantah (Boserup, 1984: 217). Buruh perempuan yang bekerja sebagai penenun biasanya berumur 25 tahun keatas, anak-anak dibawah 25 tahun biasanya bertenun hanya ketika liburan atau anak yang tidak mengecap pendidikan formal. Dalam sistem pembangian kerja keluarga, biasanya ayah bekerja sebagai petani dan ibu sebagai penenun kain. Pengintegrasian pekerjaan ayah dan ibu dalam formasi keluarga ini bertujuan agar keluarga tersebut tetap survive ${ }^{7}$.

Aktifitas bertenun di Pandai Sikek memang harus di pertahankan dan diregenerasikan dari tahun ke tahun. Untuk itu perlu dukungan dan usaha tertentu dari semua aspek dan lini masyarakat yang ada seperti pemerintah, tetua adat, masyarakat itu sendiri dan ibu-ibu rumah tangga, agar proses tersebut tetap berjalan dan konsensus dari satu gererasi ke generasi. Melihat pentingnya eksistensi tersebut Pemerintah - dalam hal ini - berfungsi untuk menstimulasi masyarakat untuk tetap dan terus bertenun dengan cara-cara yang kreatif dari segi ketenaga kerjaan, ekonomi, stabilitas harga dan sumber daya manusia agar masyarakat menyadari betul pentingnya regenerasi dan proses belajar tradisi bertenun di nagari Pandai Sikek. Hal yang perlu dipertimbangkan bahwa ekspansi pasar juga kemudian mengubah kehidupan menjadi suatu proses transaksi dimana setiap orang menghitung cost dan benefit dari setiap hubungan sosial dan praktik dimana ia terlibat (Abdullah, 2010: 112)

Dalam hal ini pemerintah kabupaten Tanah Datar sudah melakukan beberapa program dan tindakan-tindakan tertentu untuk keberlangsungan aktifitas bertenun di Pandai Sikek yang bertemakan One Village One Produck atau yang dikenal dengan istilah OVOP. Programprogram tersebut disusun dalam tabel berikut beserta anggaran dananya. Pemerintah Daerah merencanakan program-program pendorong untuk menaikkan minat masyarakat untuk bertenun di nagari Pandai Sikek. Jumlah dana yang dikeluarkanpun tidak main-main. Apabila dijumlahkan kedua program tersebut maka dari tahun 2008 sampai 2010 dana yang dianggarkan untuk keberlangsungan bertenun di nagari Pandai Sikek mencapai angka Rp3.021.406.000 (tiga milyar dua puluh satu juta empat ratus enam ribu). Jumlah tersebut merupakan penjumlahan dari dana anggaran APBD Kabupaten Tanah Datar dan dari APBD Kementrian Perindustrian. Namun menurut salah seorang masyarakat yang berinisial AA, pemerentah memang baik dalam merencanakan dan menyusun anggaran namun aplikasinya nyatanya hanya sedikit yang terlihat dan nyata, dengan kata lain pemerintah belum sepenuhnya dan betul-betul menjalankan program tersebut dengan baik.

Bapak Wali Nagari Pandai Sikek mengemukakan bahwa memang sudah banyak program yang dicanangkan oleh pemerintah dengan dana yang cukup besar, Baik dari pemerintah kota atau Kementrian Perindustrian sendiri. Namun mungkin cara mensosialisasi program tersebut yang tidak terlalu efektif dan kondusif sehingga program-program yang dicanangkan pemerintah tersebut tidak terlalu terlihat. Salah satu produk nyata dari rencana anggaran tersebut adalah Pusat Inovasi Tenun Pandai Sikek. Gedung Bangunan yang

\footnotetext{
${ }^{7}$ Lihat Peter Elias. "Family Formation, Occupational Mobility and Part Time Work". Dalam Audrey Hunt. 1988.

"Women and Paid Worker". London: Macmillan Press. HIm 83
} 
diresmikan oleh ketua Dekranas ibu Hj. Muffidah Yusuf Kalla tanggal 5 juni 2008 ini berada ji Jorong Koto Tinggi. Ketika peneliti mengobservasi tempat ini, memang terdapat banyak sekali panta disana beserta alat-alat lainnya seperti pemintal benang yang terbuat dari mesin. Selain itu ada juga alat tenun mesin sendiri dan alat-alat mahal lainnya. Namun anehnya yang bekerja atau yang bertenun disana hanya dua orang. Mereka sedang mengerjakan proyek bahan pakaian formal kantor salah satu Dinas di Batu Sangkar. Menurut ketua harian yang mendiami Pusat Inovasi ini bahwa jumlah anggota yang terdaftar mencapai $800^{8}$ (delapan ratus)orang.

Namun demikian, dewasa ini terjadi penurunan jumlah orang yang bertenun terutama perempuan. Kita tidak bisa menutup mata bahwa banyak dari generasi-generasi muda Pandai Sikek yang tidak bisa bertenun, hal ini bisa terlihat dari banyaknya keluarga pengusaha anak tenun yang khawatir mengenai eksistensi tenun Pandai Sikek karena mereka tidak memiliki anak pempuan atau anak perempuan mereka tidak bisa bertenun. Berkurangnya jumlah penenun di Pandai Sikek tentu dipengaruhi banyak faktor, baik internal maupun eksternal. Masahnya kemudian adalah bahwa semakin sedikit anggota masyarakat yang bertenun, maka semakin terkikis eksistensi identitas mereka sebagai pemilik kearifan lokal bertenun, dan dengan demikian pula semakin mereka menggalkan unsur-unsur kebudayaan mereka.

\section{Tabel I:}

Jumlah Unit Usaha dan Jumlah Tenaga Kerja Anak tenun di Pandai Sikek

\begin{tabular}{|l|l|l|}
\hline Tahun & Unit Usaha & Tenaga Kerja \\
\hline 2006 & 13 & 276 \\
\hline 2007 & 14 & 316 \\
\hline 2008 & 17 & 343 \\
\hline 2009 & 18 & 346 \\
\hline 2010 & 19 & 349 \\
\hline 2011 & 22 & 354 \\
\hline
\end{tabular}

Tabel 1. Jumlah unit usaha dan tenaga kerja pada industri logam, elektronika dan aneka yang formal (izin) dalam kurun waktu 6 tahun. (Sumber: BPS Sumatera Barat)

Dari tabel di atas bisa disimpulkan bahwa pertumbuhan jumlah unit usaha dan tenaga kerja (berizin) meningkat dari tahun ke tahun, menurut data BPS (Badan Pusat Statistik) Sumatera Barat Pertumbuan Penduduk Masyarakat nagari Pandai Sikek Adalah 3,64\% pertahunnya. Dalam kurun waktu 6 tahun yaitu dari tahun 2009-2011 hanya ada penambahan 9 unit usaha dan 78 tenaga kerja anak tenun. Kalau kita mengacu pada tabel maka hanya pada tahun 2008 saja terjadi pertambahan tenaga kerja yang cukup tinggi. Namun, apabila pertumbuhan jumlah unit usaha dan jumlah anak tenun dikomparasikan dengan jumlah angkatan kerja maka pertumbuhan tersebut tidak bisa dikatakan tinggi karena jumlah angkatan yang siap bekerja jauh lebih besar. Mengacu pada tabel di atas, keadaan ini merupakan sesuatu yang tidak harus terjadi mengingat bahwa aktifitas menenun di nagari Pandai Sikek merupakan kegiatan yang sudah ada sejak dulu dan sudah menjadi jati diri serta identitas suku bangsa. Untuk itu perlu dan menarik rasanya untuk melihat bagaimana proses belajar tradisi bertenun di nagari Pandai Sikek. Keadaan seperti ini mungkin juga yang dimaksud oleh Scott (1981) dalam bukunya moral ekonomi petani bahwa mereka seperti tenggelam dengan ketinggian air tepat di mulut mereka, ombak-ombak kecil bisa saja membuat mereka langsung tenggelam.

\footnotetext{
${ }^{8}$ Hasil wawancara penulis dengan salah soerang yang sedang mengerjakan kain tenun di Pusat Inovasi Tenun Pandai Sikek
} 


\section{Motivasi Ekonomi VS Motivasi Budaya}

Motivasi Bisa didefinisikan sebagai dorongan yang menggerakan seseorang bertingkah laku dikarenakan adanya kebutuhan - kebutuhan yang ingin dipenuhi oleh manusia. Motif juga dapat dikatakan sebagai daya penggerak dari dalam dan di dalam subjek untuk melakukan aktivitas-aktivitas tertentu demi mencapai suatu tujuan. Hampir semua informan yang ditanya dan diamati menyatakan motivasi utama mereka dalam bertenun adalah motif ekonomi, walaupun memang tidak dinyatakan secara langsung. Dengan kata lain, masyarakat tergerak untuk bertenun setiap harinya untuk menyelesaikan kain tenun karena motivasi ekonomi.

Motivasi ekonomi tersebut tidak terlepas dari faktor harga tenun itu sendiri. Biasanya anak tenun akan menyerahkan kain tenunnya ke toko (induak semang) apa bila sudah menyelesaikan songket dan selendang karena kain tenun biasanya dijual sepaket, kodek dan selendang. Kedua kain tenun tersebut berbeda ukuran dan berbeda harga namun dijual dengan satu paket. Karena ukuran dan bentuknya berbeda, maka harga dan waktu atau masa pengerjaannya juga berbeda. Ukuran kodek lebih besar dari pada ukuran selendang. Ukuran kodek biasanya 1 meter x $180 \mathrm{~cm}$ atau $200 \mathrm{~cm}$ tergantung pesanan yang biasanya diselesaikan dengan waktu minimal 15 hari. Sedangkan ukuran selendang adalah $50 \mathrm{~cm}$ x $150 \mathrm{~cm}$ dengan masa pengerajaan 1 minggu. Dengan begitu, maka harganyapun berbeda. Anak tenun menjual selendang mereka ke induk semang dengan perkisaran harga Rp300.000 sampai Rp400.000 dan harganya sangat berfariatif tergantung induk semangnya sendiri, sedangkan kodek atau songket dihargai dengan harga Rp700.000 -Rp900.000 per helainya. Dengan kata lain harga terbesar atau paling tinggi yang didapat seorang anak tenun dengan hasil produksinya yang berupa selendang dan kodek adalah Rp1.300.000 dengan masa waktu pengerjaan minimal 22 (3 minggu) hari apabila dikerjakan tiap hari.

Dengan motivasi ekonomi juga, maka induk semang akan menjual kain tersebut kepada konsumen dengan harga di atas dari harga yang diberikannya kepada anak tenun itu sendiri. Menurut apa yang peneliti dapat di lapangan, Harga satu paket selendang dan Sarung minimal adalah Rp2.700.000. dan sangat jarang hasil tenun dijual dengan harga serendah itu. Setiap toko punya harga yang bervariatif sesuai dengan penawaran si pembeli. Terlebih lagi konsumen tenun Pandai Sikek bukan hanya wisatawan dalam negeri tetapi juga dari mancanegara. Semenjak ditetapkannya Nagari Pandai Sikek segai desa wisata semakin besar pula volume jumlah wisatawan yang berkunjung dan harga tenun yang dijual kepada mereka di atas $100 \%$ dari harga normal yang diberi kepada wisatawan lokal. Tercatat harga jual satu paket kain tenun dengan harga Rp.4.000.000 sampai Rp9.000.000. kalau dibandingkan, maka harga ini sangat tidak sebanding dengan harga yang didapat oleh anak tenun itu sendiri. Sesuai dengan apa yang diuraikan di atas maka faktor harga merupakan hal yang sangat perlu dipertimbangkan dalam bertenun dalam motif ekonomi. Karena harga upah sangat jauh jaraknya dengan harga jual yang kadang dibawah UMR apabila dikalkulasikan selama 1 bulan. Dan faktor ini juga menghambat proses belajar yang terbentuk pada masyarakat.

Motivasi ekonomi ini sangat menojol dalam masyarakat karena dengan alasan yang krusial yaitu agar bisa bertahan hidup (survive). Lebih lanjut lagi, motivasi ekonomi sangat mempengaruhi kerja masyarakat. Semakin giat, rajin dan tekun masyarakat bertenun maka semakin cepat pula kain selesai dan semakin cepat mendapatkan uang dan sebaliknya, apabila bermalas-malasan dan berleha-leha maka semakin lama pula kain selesai. Dari sini terlihat jelas bahwa motivasi ekonomi lebih menonjol dari pada motivasi budaya.Tidak hanya sampai disitu, banayak juga dari masyarakat yang berhenti bertenun dan beralih ke aktifitas pertanian karena hanya dengan bertenun tidak bisa mencukupi kebutuhan sehari-hari keluarga. Hal ini 
dikarenakan uang yang dihasilkand dari bertani atau berladang lebih besar dibandingkan dengan bertenun selama satu bulan. Hal ini juga tidak terlepas dari satu motivasi, yaitu motivasi ekonomi.

Tidak bisa dipungkiri bahwa selain motivasi ekonomi, motivasi budaya juga sangat berperan dalam keberlangsungan aktifitas bertenun di Pandai Sikek. Salah satu kontorl sosial yang berbentuk lisan yaitu "sangat memalukan apabila gadis-gadis Pandai Sikek Tidak Bisa bertenun" sebenarnya sangat berpengaruh pada masyarakat itu sendiri. Semoyan yang diyakini masyarakat ini menuntut masyarakat Pandai Sikek terutama wanita untuk belajar dan harus bisa bertenun walaupun kenyataannya sekarang tidak demikian karena masih banyak anakanak yang belum bisa bertenun di atas umur 17 tahun. Masyarakat sepenuhnya sangat khawatir apabila 20-30 tahun kemudian tenun Pandai Sikek sudah tidak ada lagi atau anak tenun-anak tenun-anak tenunya adalah orang luar dari Pandai Sikek karena menurut masyarakat tenun itu adalah pusako yang harus tetap dijaga. Maka dari itu motif budaya juga sangat berperan namun yang paling menunjol adalah motif ekonomi karena memang tenun itu bernilai ekonomis. Maka akan sangat memalukan apabila pusako itu hilang atau diambil oleh orang lain, dengan kata lain masyarakat tidak bisa menjaga apa yang telah dipesankan dan sumpah nenek moyang terdahulu.

Motivasi budaya ini tidak hanya bersumber dari budaya itu sendiri, tapi bersumber dari diri sendiri, atau lebih tepatnya dari kesadaran diri. Proses belajar sebenarnya mulai dengan tumbuhnya kesadaran diri, yaitu kemampuan untuk melihat diri sendiri sebagai objek, untuk bereaksi terhadap dirinya sendiri dan untuk nilai diri sendiri. Manusia memang tidak memiliki kemampuan itu ketika lahir meskipun memang kemampuan seperti itu mutlak hukumnya untuk eksistensi di dalam masyarakat. Kesadaran diri sendiri itulah yang membuat orang bertanggung jawab atas prilakunya sendiri, dapat belajar bagaimana harus menanggapi orang lain dan untuk menerima berbagai macam-macam tugas. Salah satu aspek penting ialah pemberian nilai yang positif tergadap diri sendiri, artinya memiliki kemampuan bertenun atau bisa bertenun di Pandai Sikek adalah sesuatu yang posotif. Ini penting sebagai motivasi agar perbuatan individu dilakukan untuk kepentingan dan tidak untuk merugikan dirinya sendiri.

Kesadaran diri itu memang penting, namun kesadaran itu tidak bisa datang dengan Cuma-Cuma atau sendirinya. Biasanya kesadaran itu tumbuh beriringan dengan dewasanya anak. Semakin besar umur anak maka semakin besar pula kesaradan diri mengenai budayanya apabila ia tumbuh dan besar dalam lingkungan binaannya sendiri. Dengan ini ia akan mengetahui mengenai difinisi kultural tentang diri sendiri bahwa iya masuk kedalam struktur sosial dimana ia memiliki status dan peran serta hak dan kewajiban. Statusnya adalah bahwa ia putra daerah Pandai Sikek dan perannya adalah untuk tetap menjaga "pusakanya" tersebut. Haknya adalah dengan secara bebas mencari nafkah dengan bertenun dan kewajibannya adalah meneruskan kemahiran tersebut kepada generasi-generasi selanjutnya termasuk anak-anaknya.

Sebenanrya motivasi inilah yang paling penting untuk dijaga dan ditonjolkan, namun karena hasil tenun itu bernilai ekonomis maka yang yang menonjol adalah motivasi ekonominya. Apabila motivas budaya ini yang dipakai sebagai alasan untuk terus bertenun maka dengan kata lain kreatifitas bertenun ini akan tetap ada dan muncul dalam rauang dan waktu dalam lingkup budaya Minangkabau Masyarakat Pandai Sikek karena menjadi keharusan, selain itu jati diri sebagai suku bangsa yang meiliki kekhasan daerah tersendiri juga terbentuk. Dengan demikian keberadaan tenun ini diakui oleh masyarakat luar Pandai Sikek maupun masyarakat luar Minangkabau itu sendiri.

Sistem pasar Kapitalisme menjadi momok dan batu besar mengakibatkan masyarakat tetap berada di kelas bawah dan terkurung dalam kesadaran palsu. Kondisi ini lantas 
mengakibatkan masyarakat tidak berpindah kelas secara stratifikatisi. Alasan eksternal bahwa pendidikan formal sebagai akibat utama dalam masalah penurunan jumlah penenun terlihat sebagai instrumen simbolik yang harus dimaknai secara mandalam.

\section{Proses Belajar : Bertenun VS Pendidikan Formal}

Proses belajar merupakan salah satu proses penting demi terwujudnya satu kebudayaan. Dari proses belajar inilah masyarakat tau apa dan bagaimana iya akan bertingkah laku di lingkungan sosial atau lingkungan budayanya sesuai dengan peran dan status yang disandang. Bisa bertenun merupakan sebuah hasil proses belajar dimana hal tersebut akan menjadi jati diri dan agar bisa diterima secara baik dalam lingkungan sosial dan budayanya.

Masyarakat nagari Pandai Sikek juga merupakan elemen yang sangat penting agar proses belajar bertenun dapat terlaksana dengan baik. Dalam hal ini upaya yang telah dilaksanakan masyarakat untuk mempertahankan aktifitas ini adalah mewajibkan anak-anak mereka baik yang laki-laki ataupun perempuan untuk mampu dan bisa bertenun dan menjalankan sumpah serapah nenek moyang mereka dulu. Tidak cukup hanya sampai disitu, anak-anak yang diajari tersebut harus mengajarkannya juga kepada anak-anak mereka kelak agar terciptanya konsensus dalam hal bertenun di Pandai Sikek. Dari semua informan yang ditanya peneliti, hampir semua informan mengakui bahwa kemarihar bertenunnya diajarkan oleh ibunya sendiri atau dari keluarga luasnya seperti tente ataupun kakaknya. Artinya upaya untuk mempertahankan aktifitas bertenun ini masih ada dan muncul dalam diri masyarakat baik apakah anak tersebut diajari secara paksa oleh orang tuanya ataupun muncul dari keingin sendiri.

Umumnya di Pandai Sikek anak-anak mulai belajar bertenun dari umur 12 tahun atau ketika sudah menamatkan pendidikan sekolah dasar (SD) karena di samping kakinya belum sampai ke tijak-tijak ${ }^{9}$ yang ada di panta, waktu ini dipilih agar waktu bermain anak tidak terganggu semasa di sekolah dasar. Panjang kaki anak juga sangat menentukan. Biasanya besar panta diseting untuk orang-orang dewasa. Dengan panta sebesar itu, orang tua biasanya menunggu saja agar kaki anak tersebut memanjang secara alamiah dari pada membeli panta baru yang harganya di atas Rp1.000.000. namun pada hakikatnya tidak ada batasan umur untuk memulai belajar bertenun. Diantara masyarakat dulunya, umur 7 (tujuh) sudah mulai belajar, ada juga yang berumur 8 tahun. Hal ini karena besar postur badan dengan umur yang sama antara anak-anak sekarang dan 20 tahun yang lalu berbeda. Masa belajar anak sangat bergantung pada seberapa sering dan lama waktu yang diluangkan untuk belajar perharinya agar ia memang benar-benar bisa bertenun. Tidak ada kesepakatan antara ibu-ibu atau para anak tenun mengenai berapa banyak waktu yang harus mereka luangkan untuk belajar bertenun namun yang jelas semakin sering meluangkan waktu maka semakin besar pula kemungkinan bisa bertenun ${ }^{10}$.

Ketika proses belajar berlangsung, ada sesuatu yang menarik dimana menurut keyakinan masyarakat Pandai Sikek bahwa anak-anak yang belajar harus disediakan sari pati. Sari pati ini terdiri dari beberapa komponen yaitu uang, rokok, daun sirih dll. Hal ini sudah diajarkan secara turun temurun dari nenek moyang mereka. Masyarakat meyakini dengan adanya benda-benda tersebut maka proses belajar bertenun akan semakin mudah dan semakin

\footnotetext{
${ }^{9}$ Tijak-tijak adalah salah satu bagian dari panta yang berfungsi untuk memilah-milah benang, tijak-tijak dioperasikan dengan menggunakan kedua kaki.

${ }^{10}$ Ginting, Jonson Handrian. 2014. "Tradisi Bertenun Pada Masyarakat Pandai Sikek. Studi Kasus: Nagari Pandai Sikek, Kecamatan X Koto, Kabupaten Tanah Datar." Skripsi. Padang: Universitas Andalas
} 
cepat. Ketika anak yang sedang belajar bertenun meresa mual dan letih, dengan memakan segenggam beras yang ada pada sari pati tersebut maka rasa mual dan letih itu bisa teratasi.

Cara belajar bertenun berbeda dengan cara belajar pada umumnya. Dalam hal ini, anakanak yang dibesarkan dalam lingkungan bertenun sebenarnya sudah sangat sering melihat dan mengamati bagaimana cara bertenun, hanya saja mereka belum pernah mencobanya. Pada saat belajar, anak biasanya diajarkan motifnya saja dengan diberi contoh. Pada hakikatnya kemahiran bertenun itu membutuhkan waktu tidak sebentar, masa belajar agar anak-anak bisa menyelesaikan 1 buah kain tenun baik songket ataupun selendang sangat bervariatif, mulai dari 1 bulan sampai 2 bulan bahkan lebih. Karena bertenun itu membutuhkan sifat yang teliti dan sabar. Ibu Mainar menjelaskan sebagai berikut :

"batanun tu yo memang harus dari keinginan surang, kalau indak dari keingin surang biasonyo barajanyo lamo, ada nan 4 bulan ado jou nan alun bisa-bisa sampai kini. Batanun tu harus saba, teliti, tekun, betah dirumah taruih. Kalau indak ado keinginan untuak baraja biasonyo inyo maraso tapaso untuak batanun. Kalau alah tapaso batanun tu hasilnyo indak rancak, asal-asalan, asal jadi. Bisa-bisa ndak laku kain dek itu."

Artinya kurang lebih seperti yang tertera dibawah ini.

“ bertenun itu memang harus dari keinginan sendiri, kalau tidak dari keinginan sendiri biasanya belajarnya lama, ada masa belajarnya yang 4 bulan ada juga yang tidak bisa-bisa sampai sekarang. Selain itu, bertertenun harus sabar, teliti, tekun dan betah di rumah selalu. Biasanya kalau tidak ada keinginan untuk belajar jadinya dia merasa terpaksa untuk bertenun. Kalau bertenun terasa terpaksa hasilnya tidak bagus, asal-asalan, asal jadi, bisa-bisa kainnya tidak laku."

Sesuai dengan apa yang disampaikan ibu Mainar di atas, bisa kita simpulkan bahwa beberapa syarat agar mudah belajar bertenun adalah sifat sabar, tekun, rajin dan teliti serta keinginannya muncul dari dalam diri sendiri dan bukan atas paksaan siapapun. Mengacu pada pernyataan tersebut bahwa sifat-sifat atau syarat tersebut tidak bisa didapati pada semua anak.

Kemahiran bertenun sama halnya dengan kebudayaan dimana didapat dengan cara belajar, artinya kemarihan bertenun tidak diturunkan secara bawaan kepada generasi selanjutnya. Maka dari itu apabila seorang ibu bisa bertenun, belum tentu anaknya juga bisa bertenun dan sebaliknya, apabila ada anak yang bisa bertenenun, belum tentu ibunya juga bisa bertenun. Sebagian besar anak-anak yang belajar bertenun tidak diajarkan langsung oleh ibu kandungnya sendiri karena keluarganya tidak memiliki latar belakang bertenun, namun mereka belajar dari keluarga dan sanak famili yang bertenun. Ibu Deswita mengemukakan bahwa:

"dulu harago kain ko mahal, banyak lo pesanan. Kebetulan ayah samo ibu dari dulu memang indak ado nan batanun tapi baladang ketek-ketek. Wakatu tu ibu minta diajaan samo anak etek. Keluarga inyo dari dulu memang alah batanun juo"

Artinya kurah lebih seperti yang diuraikan dibawah ini.

"dulu harga kain tenun mahal dan banyak pesanan. Kebetulan ayah dan ibu saya dulu memang tidak ada yang bertenun tapi berladang atau berkebun kecil-kecilan. Waktu itu ibuk minta diajarkan sama anak tante, keluarganya memang dari dulu sudah bertenun." 
Dari penjelasan panjang diatas, bisa ditarik garis merah bahwa belajar bertenun memiliki beberapa aspek penting yang akan mempengaruhi keberhasilan transfer pengetahuan dari satu generasi ke generasi lain. Salah satu faktor yang sangat penting adalah permasalahan waktu. Bahwa anak-anak mulai belajar bertenun ketika sedang duduk di bangku SD (Sekolah Dasar), biasanya ketika sedang duduk di kelas V atau kelas VI.

Dinamika regulasi pendidikan formal di Indonesia mengalami beberapa kali perubahan kurikulum yang berdampak pada metode dan teknis pelaksanaan aktivitas belajar mengajar di sekolah. Dengan ditetapkanknya kurikulum 2013 sebagai panduan untuk teknis belajar dan mengajar, maka jam belajar juga ikut berubah. Berdasarkan kurikulum tersebut, jumlah jam belajar anak di Sekolah Dasar adalah enam jam sehari atau 36 jam seminggu, sudah termasuk waktu istirahat. Dengan demikian, apabila anak masuk dan mulai belajar pukul 07.00, maka anak akan pulang pada pukul 13.00. selama enam tahun, anak-anak akan menjalani rutinitas ini setiap paginya. Dengan sistem seperti ini, anak-anak memiliki waktu luang untuk belajar bertenun selama tiga jam, kerena tepat setelah solat Ashar, anak-anak akan berangkat ke mesjid atau surau untuk mengaji sampai magrib tiba. Masyarakat Pandai Sikek biasanya tidak bertenun pada malam hari karena bisa merusak mata ${ }^{11}$, maka dengan demikian, anak-anak biasanya akan mengerjakan pekerjaan rumah (PR) atau bermain dengan teman-temannya di luar rumah.

Kurikulum 2013 sebagai kurikulum baru di dunia pendidikan formal turut mempengaruhi jam belajar anak di jenjang SMP dan SMA. Sepengamatan penulis, anak-anak SMP dan SMA seringkali pulang bersamaan dengan kendaraan yang sama pada pukul 14.30. Jumlah SMP dan SMA di Nagari Pandai Sikek tidak sebanyak SD yang bisa ditemukan di tiap Jorong $^{12}$, dengan jumlah lima jorong, Nagari Pandai Sikek hanya memiliki 3 SMP atau MTs dan hanya memiliki 2 SMA atau MA. Dengan demikian, anak-anak di Pandai Sikek banyak yang sekolah ke nagari lain bahkan kabupaten lain karena memang Nagari Pandai Sikek diapit oleh dua kabupaten yang berbeda. Biasanya anak-anak akan berangkat sekolah dengan menggunakan jasa angkot atau oplet dan begitu juga saat pulang.

Kondisi seperti ini lantas akan mengakibatkan waktu luang untuk belajar bertenun akan berkurang. Untuk anak SMP dan SMA, bisanya mereka akan belajar bertenun di sore hari sampai sebelum magrib karena dari pagi sampai sore mereka menghabiskan waktu untuk belajar di sekolah sehingga waktu yang tersisa hanya sore hari, ada beberapa anak yang putus sekolah dan kemudian waktunya hanya dihabiskan untuk bertenun. Hal ini tidak berjalan seperti ini setiap hari karena ada beberapa aktivitas yang harus dilakukan terutama pekerjaan rumah, seperti mencuci, pakaian dan membersihkan rumah. Dengan demikian, terkadang dalam sehari anak tidak menyediakan waktu untuk bertenun.

Institusi pendidikan formal di pandai sikek hanya sampai jenjang SMA atau MA, tidak ada universitas atau sekolah tinggi. Anak-anak yang sudah menamatkan pendidikan sampai jenjang SMA biasanya akan melanjutkan pendidikan ke Universitas sebagai Mahasiswa. Hal ini mengakibatkan bahwa anak tidak tinggal dan menetap lagi di Pandai Sikek. Dengan demikian, anak tidak akan menyentuh panta lagi untuk bertenun. Selama penelitian berlangsung, penulis mengobservasi dan mewawancari 20 putri daerah yang melanjutkan pendidikan sampai Jenjang S1, sampai saat penelitian pada tahun 2014, 16 dari anak tersebut belum atau tidak bisa bertenun.

\footnotetext{
${ }^{11} \mathrm{Hal}$ ini disebabkan karena bertenun adalah proses menyilangkan ribuan benang vertikal dan benang horizontal dengan pola-pola tertentu, aktivitas ini membutuhkan fokus pada detail-detal jumlah benang.

12 Jorong adalah struktur pemerintahan dibawah Nagari, hal ini mungkin bisa dikonversikan sebagai kelurahan ditataran pemerintahan pada umumnya,
} 
Masyarakat Pandai Sikek sepenuhnya sadar bahwa melanjutkan pendidikan sampai kepada jenjang yang paling tinggi adalah sebuah kebutuhan serta perlu usaha keras untuk sampai kesana. Hal ini seringkali menjadi alasan kenapa anak-anak perempuan belum atau tidak bisa bertenun. seperti yang telah dijelaskan sebelumnya bahwa komoditi kain tenun menjadi bagian dari lingkaran kapitalisme dan cukup sulit keluar dari sistem tersebut, padahal menurut interpretasi penulis bahwa permasalahan inilah masalah utama dalam permasalagan ini namun anak-anak perempuan Pandai Sikek seringkali beralasan bahwa Pendidikan formal adalah faktor utama, karena kendati mereka bisa bertenunpun, mereka akan masuk ke dalam lingkaran kapitalisme.

Hal diatas baru hanya menghambat sistem pembelajaran secara fisik terkait bagaimana pengerjaan kain tenun tersebut, hal penting yang tidak bisa dinafikan juga adalah pengetahuan filosofis dari setiap motif-motif kain tenun Pandai Sikek karena sumber dari motif tersebut adalah dari alam, falsafah "alam takambang jadi guru" menjadi bagian penting dalam proses pembentukan motif. Urgensi dari hal ini adalah karena bisa bertenun tidak serta merta memberikan gambaran dan pengetahuan dari motif-motif tersebut ${ }^{13}$

\section{E. Kesimpulan}

Dinamika bertenun di Pandai Sikek mencakup berbagai permasalahan dengan kompleksitas yang luas karena banyak aktor yang bermain dan sistem yang dipertahankan.. Satu hal yang harus dimaknai secara mendalam adalah bahwa penurunan jumlah penenun di Pandai Sikek bukanlah hanya disebabkan oleh sebagai institusi pendidikan formal, tetapi juga oleh suatu proses perubahan alami yang terjadi dari dalam kebudayaan dan masyarakat itu sendiri. Namun bagaimanapun juga, kebijakan Negara sebagai institusi formal tertinggi mempersempit ruang-ruang belakar kebudayaan itu sendiri yang lambat laun akan menghilangkan tradisi itu sendiri. Pemaknaan dan interpretasi sebagai tools atau instrumen simbolik menjadikan pendidikan formal sebagai masalah dan penghambat yang tampak jelas. Sampai pada titik ini, kutipan perkataan Max waber dalam buku Tafsir kebudayaan karya Geerz (1992:2) memiliki arti yang mendalam bahwa kebudayaan adalah sebuah jaring-jaring makna.

Dalam hal ini, penulis tidak bermaksud untuk menuduh dan menghakimi bahwa pendidikan formal tidak penting, karena bagaimanapun juga masyarakat harus tetap belajar dan terus belajar karena selain proses sejarah kehidupan yang sah dan formal, pendidikan formal juga salah satu proses transfer pengetahuan pada dimensi yang berbeda dengan sosialisasi pengetahuan kebudayaan. Yang perlu dipikirkan adalah bagaimana kemudian pendidikan formal dan pendidikan kebudayaan bisa berjalan bersama tanpa menutupi salah satunya karena kurangnya jumlah anak tenun turut berkontribusi dalam deinternalisasi nilai-nilai, norma dan pengetahuan kebudayaan dan dengan demikian pada titik tertentu bisa hilang atau diambil oleh orang lain.

\footnotetext{
13 Lihat Ginting, Jonson Handrian 2013. "Motif-Motif Tenun Pandai Sikek sebagai Interpretasi dari Falsafal Alam Takambang Jadi Guru". Karya IImiah. Dipersentasikan dalam lomba karya tulis ilmiah se-kota Padang, November 2013.
} 


\section{Daftar Pustaka}

Abdullah, Irwan. 2006. “Konsutruksi dan Reproduksi Kekuasaan”. Jakarta: Pustaka Pelajar.

Boserup, Ester. 1984. "Peranan Wanita dalam Perkembangan Ekonomi”. Jakarta: Yayasan Obor Indonesia

Geerz, Clifford. 1992. “Tafsir Kebudayaan”. Yogyakarta: Kanisius.

Ginting, Jonson Handrian. 2014. "Tradisi Bertenun Pada Masyarakat Pandai Sikek. Studi Kasus: Nagari Pandai Sikek, Kecamatan X Koto, Kabupaten Tanah Datar." Skripsi. Padang: Universitas Andalas.

2013. Motif-Motif Tenun Pandai Sikek sebagai Interpretasi dari

Falsafal "Alam Takambang Jadi Guru". Karya Ilmiah. Dipersentasikan dalam lomba karya tulis ilmiah se-kota Padang, November 2013.

Elias, Peter. 1988. “Family Formation, Occupational Mobility and Part Time Work". Dalam Audrey Hunt.. "Women and Paid Worker". London: Macmillan Press.

Mizuno, Kosuke. 1996. Rural Industrialization in Indonesia Acase Study of CommunityBased Weaving Industry in West Java. Tokyo: Institute of Developing Ecomonic.

Scott, C.James. 1981. “Moral Ekonomi Petani”. Jakarta: LP3ES

Susilastuti, Dewi Haryani. Bambang Wisnu Handoyo. 1990. "Buruh Jahit Di Pedesaan Jawa:Suatu Studi Tentan Kondisi Sosial Ekonomi Dan Strategi Kelangsungan Hidup". Yogyakarta: Pusat Penelitian Kependudukan Universitas Gadjah Mada.

Tidorante, Usuluddin. Simon Sangke. 1993. "Hubungan Kerja Dan Sistem Upah Tradisional Daerah Sulawesi Tengah”. Departemen Pendidikan Dan Kebudayaan, Direktorat Jendral Kebudayaan, Direktorat Sejarah Dan Nilai Tradisional. Bagian Proyek Penelitian Pengkajian Dan Pembinaan Nilai-Nilai Budaya Sulawesi Tengah. 